\title{
Distribution and relative abundance of flyingfish (Exocoetidae) in the eastern Caribbean. II. Spawning substrata, eggs and larvae
}

\author{
Wayne Hunte ${ }^{1,2}$, Hazel A. Oxenford ${ }^{2}$, Robin Mahon ${ }^{1}$
}

${ }^{1}$ Bellairs Research Institute of McGill University, St. James, Barbados

${ }^{2}$ Marine Resource and Environmental Management Programme (MAREMP), University of the West Indies, Cave Hill, Barbados

\begin{abstract}
We investigated the distribution and relative abundance of flyingfish spawning substrata (flotsam), eggs and larvae by neuston tows at 40 stations across a 67500 square nautical mile $\left(\mathrm{nmi}^{2}\right)$ area of the eastern Caribbean from April 10 to May 6, 1988. Flotsam occurred in only $48 \%$ of the tows and in quantities $<1 \mathrm{~g} \mathrm{nmi}^{-1}$ tow. Non-buoyant flyingfish eggs characteristic of Hirundichthys affinis, Parexocoetus brachypterus and Cypselurus cyanopterus were virtually absent. Although $21 \%$ of the 3014 fish eggs collected were flyingfish eggs, all but 3 of these were pelagic eggs characteristic of Exocoetus spp. The rarity of eggs and flotsam suggests that flyingfish may typically spawn on floating material until it submerges, and/or spawn on submerged substrata. Catch rates of all fish larvae and of flyingfish larvae were significantly higher in day tows than night tows, and mean larval size was larger by night. This indicates that larvae, and particularly smaller larvae, may move downwards at night. This may be a light response, since $P$. brachypterus larvae were more abundant at the surface around full moon than new moon. Larval abundance varied significantly across the survey area for all flyingfish, and separately for $E$. volitans, $P$. brachypterus and C. cyanopterus. Small larvae of E. volitans were more abundant at oceanic than coastal stations. The reverse was true for $P$. brachypterus, indicating different spawning locations for these species. The geographical distribution of larvae of $C$. cyanopterus coincided with the adult distribution, both larvae and adults being rare in the southwest sector of the survey area near the South American mainland. Larvae of $H$. affinis were relatively rare. This rarity, and the virtual absence of eggs, is surprising given the abundance of this species in the eastern Caribbean and the fact that $H$. affinis was known to be spawning during the time of the survey. The depth at which $H$. affinis typically spawns and hatches requires further investigation.
\end{abstract}

KEY WORDS: Flyingfish - Larvae - Eggs - Spawning substrata - Neuston survey · Eastern Caribbean

\section{INTRODUCTION}

Flyingfish (Exocoetidae) are an important component of the catch in eastern Caribbean fisheries (e.g. Mahon et al. 1986, Oxenford et al. 1993), but little is known about their distribution and relative abundance, particularly in early life history stages. Using a visual survey technique for adult flyingfish in the eastern Caribbean, Oxenford et al. (1995, this issue) reported that abundance of individual species varied significantly across their survey area, and that regional distribution differed between species. The use of visual surveys to assess intraspecific relative abundance is, however, constrained by the assumption that the pro- portion of fish taking to the air is constant for a particular survey vessel, regardless of fish abundance. Moreover, the proportion of fish taking to the air is likely to be species specific such that interspecies comparisons of abundance are difficult. It is therefore prudent to complement visual surveys with other approaches to assessing distribution and relative abundance if feasible.

Fish egg and larval surveys are commonly used to assess the distribution and relative abundance of oceanic pelagic fish. The passive eggs and weakswimming larvae are vulnerable to capture, and quantitative samples of several species can be simultaneously taken over broad areas with simple plankton or 
ichthyoplankton nets (Smith \& Richardson 1977). The distribution of eggs and larvae can provide information on the spatial and temporal location of spawning areas and good fishing grounds, can improve our understanding of movement of pelagic fish through comparisons with the distributions of adults, and can provide information on unexploited stocks which may have commercial value.

Flyingfish have evolved from demersal ancestors. Although all species are now pelagic, the eggs of most are not buoyant, have filaments for attachment to substrata, and are therefore considered demersal (Collette et al. 1984). Since all life history stages of flyingfish except eggs are pelagic, it is typically assumed that adults spawn on floating substrata. The assumption is supported by several observations, and choice of spawning substratum appears flexible. For example, Breder (1938), Brown (1942), Hall (1955), Lewis et al. (1962) and Vijayaraghavan (1973) have all observed flyingfish eggs on floating Sargassum weed. Other substrata on which eggs have been found include floating seagrass, driftwood, straw, feathers, coconuts, empty bottles and nets (e.g. Munro 1954, Kovalevskaya 1982, Lao 1989). The success of the coconut branches, banana leaves and sugar cane trash used as attraction devices in flyingfish fisheries in the eastern Caribbean depends on their potential as spawning substrata, and eggs are frequently deposited on these devices and on the gillnets used for fish capture (Khokiattiwong 1988).

Lao (1989) investigated seasonal variation in abundance of flotsam (as potential flyingfish spawning substratum), and of eggs, larval and juvenile flyingfish at 3 stations off the west coast of Barbados. He reported that spawning substrata and eggs were rare and that flyingfish larvae and juveniles were most abundant between February and June. There has been no attempt to assess the distribution and abundance of flyingfish spawning substrata, eggs or larvae throughout the eastern Caribbean. It is therefore not known whether the distribution of floating spawning substrata may influence the distribution of flyingfish spawning, whether distinct spawning areas exist and can be detected, or whether the distribution and relative abundance of adults can be inferred from the distribution and relative abundance of eggs and larvae.

The objectives of this study were to use visual surveys and neuston samples to investigate the distribution and relative abundance of surface flotsam (as flyingfish spawning substratum) in the eastern Caribbean, to use neuston samples to investigate the distribution and relative abundance of flyingfish eggs and larvae in the eastern Caribbean, and to compare the data with those obtained on the distribution and rela- tive abundance of adult flyingfish using visual surveys (Oxenford et al. 1995).

\section{METHODS}

Study area. The distribution and relative abundance of flyingfish spawning substrata, eggs and larvae in the eastern Caribbean was surveyed during a 1 mo cruise (April 10 to May 6, 1988) on RV 'Provider', conducted during the known spawning periods of Hirundichthys affinis (Günther) (November to June; Storey 1983, Khokiattiwong 1988) and Parexocoetus brachypterus (Gosse) (March to September; Khokiattiwong 1988) in the study area, and in the period of peak abundance of larvae of $H$. affinis, Exocoetus volitans (Linnaeus) and P. brachypterus off Barbados (February to July; Lao 1989). A total of 40 sampling stations, each positioned 50 nautical miles (nmi) apart, formed a sampling grid over the survey area which covered 67500 $\mathrm{nmi}^{2}$ of the eastern Caribbean (Fig. 1).

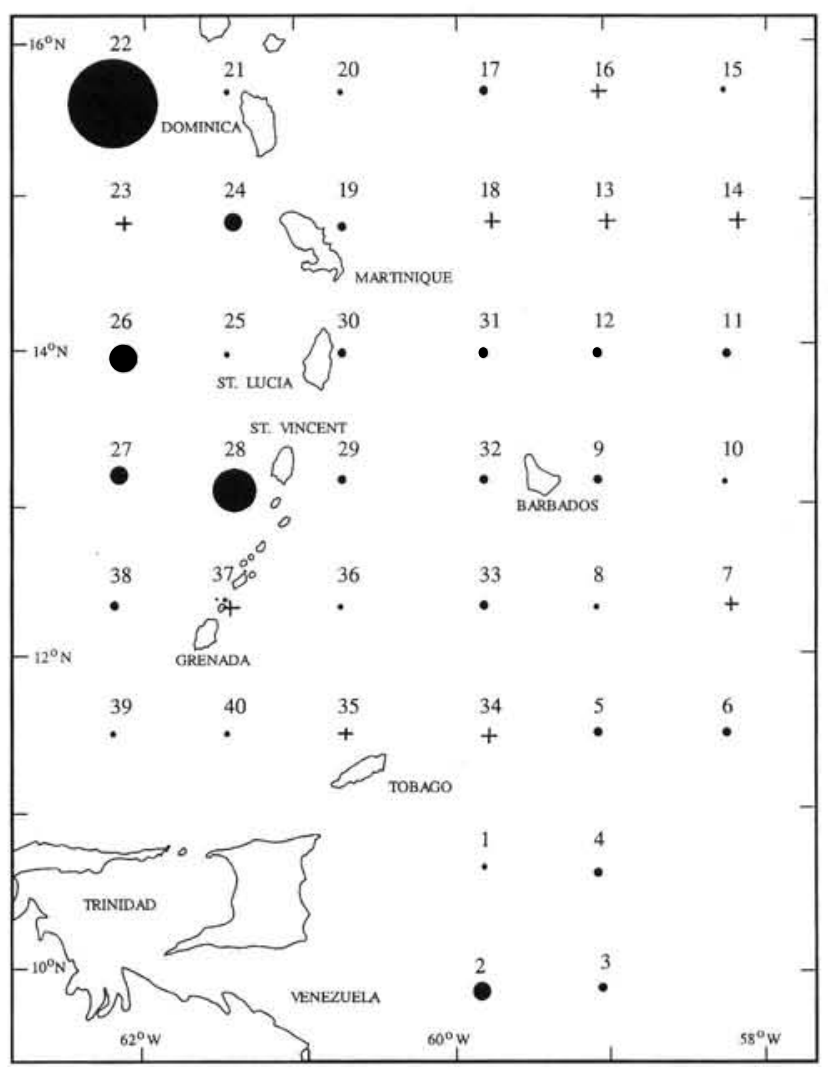

Fig. 1. Relative abundance of flyingfish spawning substrata (flotsam; of which $88 \%$ is Syringodium filiforme) in neuston tows sampled by day and night across the survey area. Even numbers indicate night stations and odd numbers day stations. Area of circle is proportional to the mean abundance (range is 0 to $22.82 \mathrm{~g} \mathrm{nmi}^{-1}$ tow). (+) station without flotsam 
Classification. Spawning substratum was considered to be any floating material which may be suitable for deposition of flyingfish eggs (subsequently referred to as flotsam). This included anthropogenic items (tar balls, wood, plastic, string) and natural items of marine (seagrasses and algae) and terrestrial (leaves and seeds) origin.

Flyingfish eggs, except those of the genera Exocoetus and Prognichthys, are non-buoyant. They were distinguished from other fish eggs by their large size, and/or by the presence of numerous filaments characteristic of non-buoyant flyingfish eggs and of Prognichthys spp. These filaments are species specific, allowing filament-bearing eggs to be identified to species (Kovalevskaya 1982, Collette et al. 1984). The non-filament-bearing, buoyant eggs of Exocoetus spp. are large and have a smooth membrane (Collette et al. 1984). They were separated into eggs of E. volitans and E. obtusirostris (Günther) on the basis of size (1.7 to $2.0 \mathrm{~mm}$ diameter for the former; 2.8 to $3.1 \mathrm{~mm}$ for the latter; Bruun 1935, Breder 1938).

Nomenclature of early life history stages of fish (larvae, fry, post-larvae, juveniles) varies with discipline and species, and is often determined by size and behaviour (Kendall et al. 1984). Based on morphological criteria during development, Balon (1985) concludes that flyingfish have no larval stage. We agree with this, but for consistency with all previous studies of flyingfish, we have termed all flyingfish taken by the neuston gear as larvae. Flyingfish larvae were easily distinguished from other fish larvae by the presence of 'wings', i.e. enlarged pectoral fins and, in most genera, enlarged pelvic fins. Identification to species was possible using the taxonomic descriptions of Breder (1938), Imai (1959, 1960), Evans (1961), Lewis (1961), Kovalevskaya (1964) and Lao (1989). Briefly, Hirundichthys affinis was recognised by greatly enlarged translucent pectoral and pelvic fins of approximately equal size; $H$. speculiger (Cuvier \& Valenciennes) by greatly enlarged pectoral and pelvic fins with pigment around the outer margins; Exocoetus volitans by enlarged pectoral fins, small pelvic fins and a dark spot near the caudal peduncle; $E$. obtusirostris by highly enlarged pectoral fins, small pelvic fins and an enlarged head; Parexocoetus brachypterus by a pair of distinct black barbels; Cypselurus cyanopterus (Cuvier \& Valenciennes) by small white barbels; and Prognichthys gibbifrons (Cuvier \& Valenciennes) by a darkly pigmented body and fins, large pectoral fins and particularly large pelvic fins.

Sampling procedure. Flotsam, eggs and larvae were collected by day and night using a neuston sampler, which was a modified version of the Sameoto \& Jarosczynski (1969) otter surface sampler and is described in detail by Lao (1989). It consisted of an alu- minium box frame with two $0.75 \times 0.5 \mathrm{~m}$ elevator fins and a $1 \times 0.5 \mathrm{~m}$ opening to which a $6 \mathrm{~m}$ long neuston net $(1.27 \mathrm{~mm}$ square mesh) was fixed. It was towed from a $3.5 \mathrm{~m}$ boom, extended over the starboard aft quarter of the ship, by an adjustable towing bridle that was attached to the side of the frame such that the net tracked away from the ship and avoided the turbulence of the ship's wake. The sampler was towed at between 2.8 and 4.0 knots depending on sea conditions, and at a bridle length and fin setting which ensured that the mouth of the sampler remained only partially submerged, sampling to a water depth of approximately $0.25 \mathrm{~m}$. Tows were standardised to $15 \mathrm{~min}$, which represented approximately $1 \mathrm{nmi}$, and actual tow distance was measured to the nearest $0.01 \mathrm{nmi}$ by a trailing log. Four tows were conducted at each sampling station (except at Stn 26 where gear failure caused the loss of 1 tow), perpendicular to the swell direction and approximately $0.5 \mathrm{nmi}$ apart. A total of 159 tows ( 80 day tows at the 20 day stations and 79 night tows at the 20 night stations) were completed. Night tows were conducted between 23:00 and 04:00 h, and day tows between 08:00 and 15:00 h.

Flotsam was also recorded whenever observed during the visual surveys conducted for adult flyingfish over the same survey area. Details of the visual survey methodology are given in Oxenford et al. (1995).

Sample treatment. Neuston samples were stored in $5 \%$ buffered formalin. They were later sorted for flotsam, which was grouped into the categories previously described and weighed to the nearest $0.01 \mathrm{~g}$, for flyingfish eggs, which were identified and counted, and for flyingfish larvae, which were identified, counted and measured for fork length (FL) to the nearest $0.1 \mathrm{~mm}$. The weight of flotsam, number of larvae and number of eggs collected per tow were then adjusted to a standard tow distance of $1 \mathrm{nmi}$. The mean weight (for flotsam) and number (for eggs and larvae) per $1 \mathrm{nmi}$ tow was used as the index of abundance.

Environmental factors. Surface water samples were collected at each sampling station and analysed for temperature, salinity, total reactive phosphorous $\left(\mathrm{PO}_{4}\right.$ P) and oxidised nitrogen $\left(\mathrm{NO}_{3}-\mathrm{NO}_{2}-\mathrm{N}\right)$, as described by Oxenford et al. (1995). Moon phase was also recorded at each station by coding it from 0 at new moon to 14 at full moon.

Statistical analyses. All data were tested for normality and homogeneity of variance. Data violating the assumptions were square-root transformed $(\sqrt{x+0.5})$. Data which remained non-normal after transformation were analysed non-parametrically. Differences between stations or station groups in egg abundance, larval abundance and environmental variables were analysed using ANOVAs for normal or normalised data, and Kruskal-Wallis tests for non-normal data. 
Differences in larval abundance and larval size between day and night tows were analysed using Mann-Whitney tests. Since larval abundance indices differed significantly between day and night, comparisons between stations have been made separately for day and night tows. Comparisons between stations have been made for all flyingfish combined, and separately for the more common species.

\section{RESULTS}

\section{Abundance of spawning substrata (flotsam)}

Flotsam occurred in only $43 \%$ of the neuston tows with a mean abundance of only $0.87 \mathrm{~g} \mathrm{nmi}^{-1}$ tow (Table 1). Seagrass accounted for $88 \%$ of the total flotsam by weight, but only occurred at 8 of the 40 sampling stations, notably those west (leeward) of the Lesser Antilles island chain (Fig. 1). Wood and tar balls were the other items occurring in more than 10 of the tows, but in very low abundance $\left(<0.1 \mathrm{~g} \mathrm{nmi}^{-1}\right.$ tow $)$. Wood was more widely distributed than tar balls (14 compared to 11 stations), but was less common, occurring in fewer tows and smaller quantities (Table 1). There were only 29 sightings of flotsam items during $159 \mathrm{~h}$ of visual survey along 34 straight-line transects, covering $950 \mathrm{nmi}$ of the survey area (i.e. 0.03 items $\mathrm{nmi}^{-1}$ of visual survey transect). The flotsam observed consisted of 19 items of anthropogenic origin, 7 natural items of terrestrial origin and 3 natural items of marine origin. These results suggest that surface flotsam was rare throughout the survey area.

Table 1. Abundance (mean weight flotsam nmi-1 tow) and frequency of occurrence of flotsam (spawning substratum) collected by neuston tows across the survey area. Occurrence is given as number of stations with flotsam, and number of tows with flotsam

\begin{tabular}{|lcrcr|}
\hline $\begin{array}{l}\text { Flotsam } \\
\text { type }\end{array}$ & $\begin{array}{c}\text { Abund. } \\
\left(\mathrm{g} \mathrm{nmi}^{-1}\right)\end{array}$ & $\begin{array}{c}\% \text { total } \\
\text { weight }\end{array}$ & $\begin{array}{c}\text { Occurr. } \\
\text { by station } \\
\mathrm{n}=40\end{array}$ & $\begin{array}{c}\text { Occurr. } \\
\text { by tow } \\
\mathrm{n}=159\end{array}$ \\
\hline Seagrass & 0.77 & 87.6 & 8 & 25 \\
Tar balls & 0.04 & 4.6 & 11 & 22 \\
Wood & 0.02 & 2.8 & 14 & 18 \\
Plastic & 0.02 & 2.0 & 5 & 9 \\
Miscellaneous & 0.01 & 1.3 & 6 & 7 \\
String & 0.01 & 0.8 & 6 & 7 \\
Leaves & $<0.01$ & 0.5 & 5 & 6 \\
Sargassum & $<0.01$ & 0.2 & 1 & 1 \\
Mahogany seeds & $<0.01$ & 0.2 & 2 & 2 \\
None & - & - & 8 & 91 \\
Overall & 0.87 & 100 & 32 & 68 \\
\hline
\end{tabular}

\section{Abundance of eggs}

Fish eggs occurred in $94 \%$ of the neuston tows with a mean abundance of 22 eggs nmi $^{-1}$ tow (Table 2). Of the 3014 fish eggs collected, $621(21 \%)$ were flyingfish eggs. Of these, only 3 were eggs of Hirundichthys affinis. The remainder were eggs of Exocoetus spp., 131 ( $21 \%)$ being E. volitans and $487(79 \%)$ E. obtusirostris.

Table 2. Abundance (mean number of eggs $\mathrm{nmi}^{-1}$ tow) of all fish eggs, and eggs of Exocoetus volitans, E. obtusirostris and Hirundichthys affinis, as indicated by neuston tows at each station across the survey area. Station locations are shown in Fig. 1. Values are means of 4 tows except at Stn 26 where there were 3 tows

\begin{tabular}{|c|c|c|c|c|}
\hline $\begin{array}{c}\text { Station } \\
\text { no. }\end{array}$ & $\begin{array}{l}\text { All } \\
\text { fish }\end{array}$ & $\begin{array}{c}\text { Exocoetus } \\
\text { volitans }\end{array}$ & $\begin{array}{l}\text { Exocoetus } \\
\text { obtusirostris }\end{array}$ & $\begin{array}{c}\text { Hirundichthys } \\
\text { affinis }\end{array}$ \\
\hline 1 & 9.69 & 0 & 0 & 0 \\
\hline 2 & 24.42 & 0 & 0.31 & 0 \\
\hline 3 & 2.82 & 0 & 0 & 0 \\
\hline 4 & 13.72 & 1.67 & 0.26 & 0 \\
\hline 5 & 13.65 & 1.35 & 0 & 0 \\
\hline 6 & 7.28 & 0.61 & 0.30 & 0.86 \\
\hline 7 & 8.63 & 0.31 & 0 & 0 \\
\hline 8 & 22.62 & 0 & 0 & 0 \\
\hline 9 & 15.69 & 0 & 0 & 0 \\
\hline 10 & 19.39 & 1.48 & 0.31 & 0 \\
\hline 11 & 17.02 & 0.91 & 0 & 0 \\
\hline 12 & 5.44 & 0 & 0 & 0 \\
\hline 13 & 11.14 & 0 & 0 & 0 \\
\hline 14 & 20.30 & 4.71 & 0.36 & 0 \\
\hline 15 & 10.19 & 0 & 0.32 & 0 \\
\hline 16 & 11.11 & 0 & 0 & 0 \\
\hline 17 & 41.29 & 0 & 0 & 0 \\
\hline 18 & 16.02 & 0 & 0 & 0 \\
\hline 19 & 9.82 & 2.75 & 0 & 0 \\
\hline 20 & 23.80 & 1.85 & 0 & 0 \\
\hline 21 & 50.96 & 1.33 & 0 & 0 \\
\hline 22 & 4.80 & 0 & 0 & 0 \\
\hline 23 & 12.31 & 0.87 & 0 & 0 \\
\hline 24 & 16.53 & 0.84 & 0 & 0 \\
\hline 25 & 5.65 & 0.21 & 0 & 0 \\
\hline 26 & 17.98 & 2.25 & 0 & 0 \\
\hline 27 & 20.17 & 1.28 & 0 & 0 \\
\hline 28 & 20.59 & 1.53 & 0 & 0 \\
\hline 29 & 15.83 & 1.71 & 0 & 0 \\
\hline 30 & 6.26 & 0.75 & 0 & 0 \\
\hline 31 & 6.81 & 0.45 & 0 & 0 \\
\hline 32 & 6.74 & 0 & 0 & 0 \\
\hline 33 & 11.59 & 0 & 0 & 0 \\
\hline 34 & 4.71 & 1.09 & 0 & 0 \\
\hline 35 & 3.71 & 0.27 & 0 & 0 \\
\hline 36 & 18.44 & 6.09 & 0 & 0 \\
\hline 37 & 162.51 & 2.40 & 126.35 & 0 \\
\hline 38 & 14.52 & 0 & 0.56 & 0 \\
\hline 39 & 11.08 & 0.27 & 0 & 0 \\
\hline 40 & 148.88 & 0.57 & 0 & 0 \\
\hline $\begin{array}{l}\text { Overall } \\
\text { mean }\end{array}$ & 21.63 & 0.93 & 3.24 & 0.02 \\
\hline
\end{tabular}


Table 3. Abundance, by number and \% occurrence, of fish larvae by family collected by day and night neuston tows across the survey area

\begin{tabular}{|c|c|c|c|c|c|c|}
\hline \multirow[t]{2}{*}{ Family } & \multicolumn{2}{|c|}{ Day $(n=80)$} & \multicolumn{2}{|c|}{ Night $(\mathrm{n}=79)$} & \multicolumn{2}{|c|}{ Total $(\mathrm{n}=159)$} \\
\hline & No. & $\%$ & No. & $\%$ & No. & $\%$ \\
\hline Hemiramphidae & 5565 & 62.2 & 25 & 0.6 & 5590 & 42.2 \\
\hline Myctophidae & 19 & 0.2 & 2114 & 48.7 & 2133 & 16.1 \\
\hline Exocoetidae & 1375 & 15.4 & 298 & 6.9 & 1673 & 12.6 \\
\hline Mullidae & 1362 & 15.2 & 2 & 0.1 & 1364 & 10.3 \\
\hline Carangidae & 70 & 0.8 & 388 & 8.9 & 458 & 3.5 \\
\hline Anguillidae & 1 & $<0.1$ & 430 & 9.9 & 431 & 3.3 \\
\hline Nomeidae & 50 & 0.6 & 326 & 7.5 & 376 & 2.8 \\
\hline Scombridae & 42 & 0.5 & 191 & 4.4 & 233 & 1.8 \\
\hline Dactylopteridae & 196 & 2.2 & 1 & $<0.1$ & 197 & 1.5 \\
\hline Bothidae & 2 & $<0.1$ & 159 & 3.7 & 161 & 1.2 \\
\hline Mugilidae & 142 & 1.6 & 14 & 0.3 & 156 & 1.2 \\
\hline Gonostomatidae & 15 & 0.2 & 105 & 2.4 & 120 & 0.9 \\
\hline Coryphaenidae & 27 & 0.3 & 57 & 1.3 & 84 & 0.6 \\
\hline Unidentified & 17 & 0.2 & 65 & 1.5 & 82 & 0.6 \\
\hline Balistidae & 2 & $<0.1$ & 70 & 1.6 & 72 & 0.5 \\
\hline Tetraodontidae & 37 & 0.4 & 14 & 0.3 & 51 & 0.4 \\
\hline Istiophoridae & 23 & 0.3 & 7 & 0.2 & 30 & 0.2 \\
\hline Holocentridae & 0 & 0 & 23 & 0.5 & 23 & 0.2 \\
\hline Belonidae & 3 & $<0.1$ & 18 & 0.4 & 21 & 0.2 \\
\hline Syngnathidae & 0 & 0 & 6 & 0.1 & 6 & 0.1 \\
\hline Acanthuridae & 0 & 0 & 6 & 0.1 & 6 & 0.1 \\
\hline Serranidae & 0 & 0 & 5 & 0.1 & 5 & $<0.1$ \\
\hline Paralepidae & 0 & 0 & 4 & 0.1 & 4 & $<0.1$ \\
\hline Xiphidae & 3 & $<0.1$ & 1 & $<0.1$ & 4 & $<0.1$ \\
\hline Monacanthidae & 0 & 0 & 3 & 0.1 & 3 & $<0.1$ \\
\hline Lutjanidae & 0 & 0 & 2 & 0.1 & 2 & $<0.1$ \\
\hline Synodontidae & 0 & 0 & 2 & 0.1 & 2 & $<0.1$ \\
\hline Diodontidae & 0 & 0 & 1 & $<0.1$ & 1 & $<0.1$ \\
\hline Echeneidae & 0 & 0 & 1 & $<0.1$ & 1 & $<0.1$ \\
\hline Total & 8951 & 67.4 & 4338 & 32.6 & 13289 & 100 \\
\hline
\end{tabular}

Exocoetus volitans $(63 \%)$, Parexocoetus brachypterus $(21 \%)$, Cypselurus cyanopterus $(4 \%)$, Hirundichthys affinis $(2 \%)$, Prognichthys gibbifrons $(1 \%), H$. speculiger $(0.2 \%)$ and $E$. obtusirostris $(0.2 \%)$. The Exocoetidae complex comprised $9 \%$ of the catch. The relative abundance of flyingfish species was similar in day and night tows with $E$. volitans, $P$. brachypterus and C. cyanopterus ranking 1, 2 and 3 respectively (Table 4).

A total of 1673 flyingfish larvae was collected, with a mean abundance of 11.92 fish $\mathrm{nmi}^{-1}$ tow and a mean size of $13.47 \mathrm{~mm}$ FL. Abundance of flyingfish larvae was significantly greater in day tows than night tows (Tables 4 \& 5; Mann-Whitney test: $Z=-7.99, \mathrm{n}=$ $159, \mathrm{p}<0.001$ ), and mean larval size was significantly greater at night (mean for night: $31.6 \mathrm{~mm}$ FL, mean size for day: $9.1 \mathrm{~mm}$ FL; Mann-Whitney test: $Z=20.902, \mathrm{n}=1402, \mathrm{p}<$ 0.001). Consequently, day and night tows have been considered separately in subsequent analyses.

Abundance of flyingfish larvae differed significantly between stations across the survey area (Table 5; ANOVA for day samples: $F=8.406$, $\mathrm{n}=80, \mathrm{p}<0.001$; Kruskal-Wallis test for night samples: $H=42.450, \mathrm{n}=79, \mathrm{p}$

The $3 \mathrm{H}$. affinis eggs were collected in a single tow at Stn 6, approximately $130 \mathrm{nmi}$ east of Tobago (Table 2, Fig. 1). The eggs of $E$. volitans occurred in low abundance and were spread across $60 \%$ of the stations; the eggs of E. obtusirostris were collected primarily at a coastal station (Stn 37) north of Grenada (Table 2, Fig. 1). $=0.002$ ). There was no apparent geographical pattern to the variation in abundance in day samples (smaller larvae), but a weak tendency for abundance to be lower in a band running northeast between the Lesser Antilles island chain and Barbados and Tobago in night samples (larger larvae) (Fig. 2).

\section{Abundance of larvae}

A total of 13289 larval fish comprising at least 28 different families was collected by the 159 neuston tows (Table 3). Flyingfish (Exocoetidae) was the third most common family, comprising $13 \%$ of the total catch (Table 3). There were 9 flyingfish species, 7 of which were identified to species and 2 of which remained unidentified. The latter are subsequently referred to as the Exocoetidae complex. In order of decreasing abundance in the tows, the species were
Table 4. Abundance (overall mean number of fish $\mathrm{nmi}^{-1}$ tow) of flyingfish larvae collected by day and night neuston tows across the survey area

\begin{tabular}{|c|c|c|c|c|}
\hline \multirow[t]{2}{*}{ Species } & \multicolumn{2}{|c|}{ Day $(\mathrm{n}=80)$} & \multicolumn{2}{|c|}{ Night $(\mathrm{n}=79)$} \\
\hline & Abundance & $\%$ & Abundance & $\%$ \\
\hline Exocoetus volitans & 13.13 & 67.4 & 1.89 & 44.3 \\
\hline Parexocoetus brachypterus & 3.33 & 17.1 & 1.57 & 36.8 \\
\hline Exocoetidae complex & 1.91 & 10.2 & 0.15 & 3.5 \\
\hline Cypselurus cyanopterus & 0.68 & 3.5 & 0.22 & 5.2 \\
\hline Hirundichthys affinis & 0.28 & 1.4 & 0.17 & 3.9 \\
\hline Prognichthys gibbifrons & 0.07 & 0.4 & 0.18 & 4.1 \\
\hline Hirundichthys speculiger & 0 & 0 & 0.05 & 1.1 \\
\hline Exocoetus obtusirostris & 0 & 0 & 0.04 & 0.9 \\
\hline All flyingfish & 19.47 & 100 & 4.26 & 100 \\
\hline
\end{tabular}


Table 5. Abundance (mean number of fish nmi ${ }^{-1}$ tow) of all flyingfish larvae, and of the most common species (Exocoetus volitans, Parexocoetus brachypterus, Cypselurus cyanopterus) collected by day and night neuston tows across the survey area. Station locations are shown in Fig. 1. Values are means of 4 tows, except at $\operatorname{Stn} 26$ where there were 3 tows

\begin{tabular}{|c|c|c|c|c|c|c|c|c|c|}
\hline $\begin{array}{l}\text { Station } \\
\text { no. }\end{array}$ & $\begin{array}{c}\text { All } \\
\text { flyingfish }\end{array}$ & $\begin{array}{c}\text { E. } \\
\text { volitans }\end{array}$ & $\begin{array}{c}P . \\
\text { brachypterus }\end{array}$ & $\begin{array}{c}\text { C. } \\
\text { cyanopterus }\end{array}$ & $\begin{array}{l}\text { Station } \\
\text { no. }\end{array}$ & $\begin{array}{c}\text { All } \\
\text { flyingfish }\end{array}$ & $\begin{array}{c}\text { E. } \\
\text { volitans }\end{array}$ & $\begin{array}{c}P . \\
\text { brachypterus }\end{array}$ & $\begin{array}{c}\text { C. } \\
\text { cyanopterus }\end{array}$ \\
\hline 1 & 32.62 & 31.01 & 0 & 0.27 & 2 & 3.48 & 0 & 0.93 & 0 \\
\hline 3 & 12.27 & 8.51 & 1.07 & 0 & 4 & 8.69 & 6.79 & 1.38 & 0 \\
\hline 5 & 12.29 & 9.31 & 0 & 1.26 & 6 & 8.36 & 3.31 & 3.96 & 0.64 \\
\hline 7 & 10.19 & 8.04 & 0 & 0.29 & 8 & 1.27 & 0.67 & 0.30 & 0 \\
\hline 9 & 13.82 & 12.00 & 0 & 0 & 10 & 1.21 & 0.61 & 0 & 0 \\
\hline 11 & 27.42 & 25.63 & 0 & 1.17 & 12 & 2.23 & 0.84 & 0 & 0.87 \\
\hline 13 & 19.91 & 17.89 & 0 & 0.48 & 14 & 1.18 & 0.91 & 0 & 0 \\
\hline 15 & 19.07 & 15.24 & 0.32 & 2.01 & 16 & 4.14 & 3.24 & 0.29 & 0 \\
\hline 17 & 3.89 & 1.32 & 0 & 1.93 & 18 & 4.16 & 2.59 & 0 & 1.05 \\
\hline 19 & 25.97 & 21.91 & 0 & 0.88 & 20 & 0.36 & 0 & 0 & 0 \\
\hline 21 & 2.97 & 0.80 & 0.26 & 0.84 & 22 & 3.71 & 2.13 & 0.53 & 0.52 \\
\hline 23 & 37.83 & 24.59 & 0 & 2.42 & 24 & 6.99 & 4.79 & 0.57 & 0.29 \\
\hline 25 & 2.24 & 1.12 & 0.22 & 0 & 26 & 5.24 & 1.87 & 3.37 & 0 \\
\hline 27 & 34.54 & 30.78 & 2.05 & 0.64 & 28 & 13.09 & 0.30 & 12.48 & 0 \\
\hline 29 & 10.25 & 6.82 & 0.29 & 0 & 30 & 10.72 & 8.20 & 1.02 & 0.75 \\
\hline 31 & 24.89 & 18.65 & 0 & 1.13 & 32 & 2.49 & 1.09 & 0.83 & 0 \\
\hline 33 & 35.21 & 27.23 & 0 & 0.32 & 34 & 2.75 & 0.56 & 1.65 & 0 \\
\hline 35 & 16.80 & 0.28 & 16.52 & 0 & 36 & 1.38 & 0 & 1.09 & 0.28 \\
\hline 37 & 11.32 & 0.54 & 10.78 & 0 & 38 & 2.60 & 0 & 2.60 & 0 \\
\hline 39 & 35.98 & 0.89 & 35.09 & 0 & 40 & 1.41 & 0 & 0.83 & 0 \\
\hline Means & 19.47 & 13.13 & 3.33 & 0.68 & Means & 4.26 & 1.89 & 1.57 & 0.22 \\
\hline
\end{tabular}

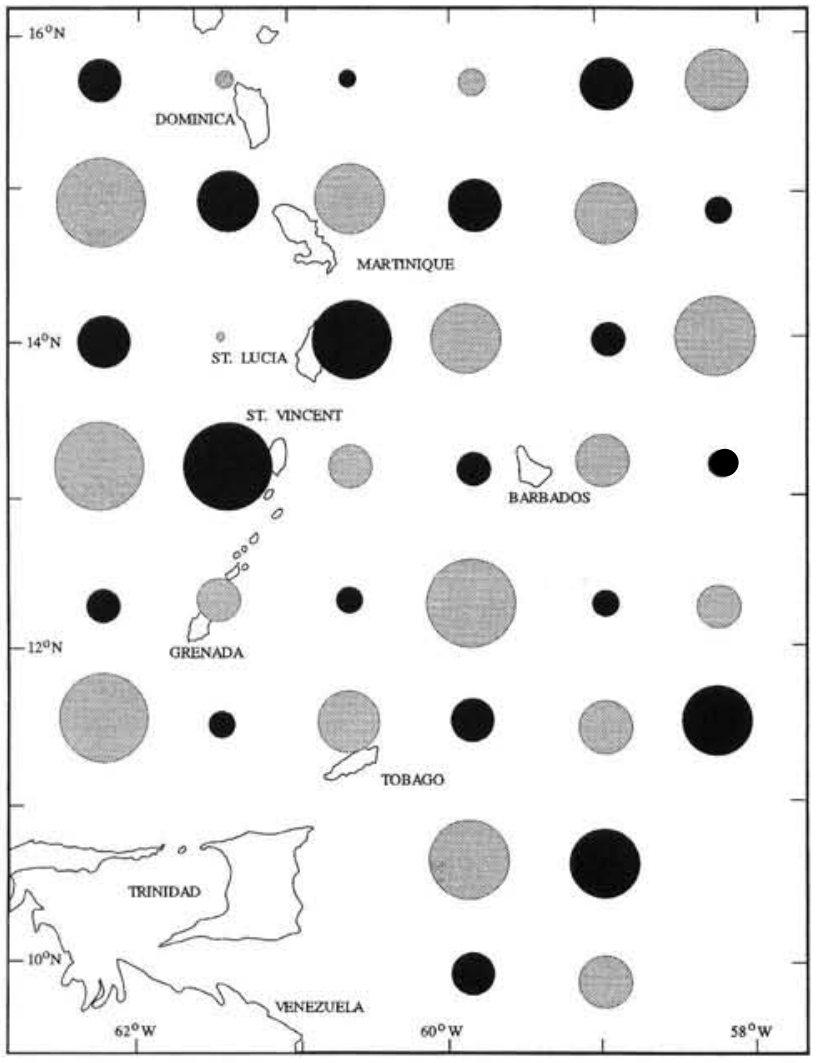

Salinity, temperature, $\mathrm{PO}_{4}-\mathrm{P}$ and $\mathrm{NO}_{3}-\mathrm{NO}_{2}-\mathrm{N}$ of surface waters differed significantly across the survey area (Oxenford et al. 1995), but were not correlated with abundance of flyingfish larvae in either day (smaller larvae) or night (larger larvae) tows (Table 6). Non-linear regressions were attempted to investigate whether there were any environmental optima, but they did not improve the fit between larval abundance and any of the environmental variables. Flyingfish larval abundance was not correlated with moon phase in either day or night tows (Spearman rank correlation: for day samples, i.e. smaller larvae, $r_{s}=0.179, p=$ 0.436 ; for night samples, i.e. larger larvae, $r_{s}=0.227, p$ $=0.323 ; \mathrm{n}=20$ in both cases); and was not correlated with flotsam abundance in day tows (smaller larvae) (Spearman rank correlation: $\mathrm{r}_{\mathrm{s}}=-0.002, \mathrm{n}=20, \mathrm{p}=$ 0.995). However, abundance was correlated with flotsam abundance in night tows (larger larvae) (Spearman rank correlation: $\mathrm{r}_{\mathrm{s}}=0.493, \mathrm{n}=20, \mathrm{p}=0.032$ ).

Fig. 2. Relative abundance of larval flyingfish in neuston tows sampled by $(\odot)$ day (small larvae) and by $(\bullet)$ night (large larvae) across the survey area. Area of circle is proportional to the mean abundance for each data set separately (range for day samples is 2.24 to 37.83 fish $\mathrm{nmi}^{-1}$ tow; range for night samples is 0.36 to 13.09 fish $\mathrm{nmi}^{-1}$ tow) 
Table 6. Spearman rank correlation coefficients between surface water characteristics and abundance (mean number of fish $\mathrm{nmi}^{-1}$ tow) of flyingfish larvae taken by day and night neuston tows at stations across the survey area. Means represent the mean of 4 tows at each station, except at Stn 26 where there were 3 tows

\begin{tabular}{|c|c|c|c|}
\hline \multirow{2}{*}{$\begin{array}{l}\text { Surface water } \\
\text { characteristic }\end{array}$} & & \multicolumn{2}{|c|}{ Flyingfish larvae abundance } \\
\hline & & Day & Night \\
\hline \multirow[t]{3}{*}{ Salinity } & $r_{s}$ & -0.148 & -0.407 \\
\hline & $\mathrm{n}$ & 15 & 15 \\
\hline & $\mathrm{p}$ & 0.579 & 0.128 \\
\hline \multirow[t]{3}{*}{$\mathrm{PO}_{4}-\mathrm{P}$} & $r_{s}$ & 0.132 & -0.127 \\
\hline & $\mathrm{n}$ & 19 & 20 \\
\hline & $\mathrm{p}$ & 0.575 & 0.581 \\
\hline \multirow[t]{3}{*}{$\mathrm{NO}_{3}-\mathrm{NO}_{2}-\mathrm{N}$} & $r_{s}$ & -0.249 & -0.017 \\
\hline & $\mathrm{n}$ & 17 & 19 \\
\hline & $\mathrm{p}$ & 0.325 & 0.943 \\
\hline \multirow{3}{*}{ Temperature } & $r_{s}$ & -0.092 & 0.104 \\
\hline & $\mathrm{n}$ & 20 & 20 \\
\hline & $\mathrm{p}$ & 0.689 & 0.651 \\
\hline
\end{tabular}

\section{Exocoetus volitans}

A total of 1062 larvae of Exocoetus volitans with a mean abundance of 7.54 fish $\mathrm{nmi}^{-1}$ tow and a mean size of $11.42 \mathrm{~mm}$ FL was collected by the 159 neuston tows over the survey area. As for all larval flyingfish, abundance of $E$. volitans larvae was significantly greater in day tows than night tows (Tables 4 \& 5; Mann-Whitney test: $Z=6.895, \mathrm{n}=159, \mathrm{p}<0.001$ ), and mean larval size was significantly greater at night (Fig. 3; Mann-Whitney test: $Z=-13.25, \mathrm{n}=883, \mathrm{p}<$ 0.001). The size distribution in night samples was bimodal, the smaller mode consisting of the same size fish as taken in day tows (Fig. 3). Day and night samples have been considered separately in subsequent analyses, with the smaller mode being omitted from night samples to ensure that day samples represent the smaller size class and night samples exclusively the larger size class.

Abundance of Exocoetus volitans larvae varied significantly between stations across the survey area (Table 5; Kruskal-Wallis test: for day samples, i.e. smaller larvae, $H=66.534, \mathrm{n}=80, \mathrm{p}<0.001$; for night samples, i.e. larger larvae, $H=43.924, \mathrm{n}=79, \mathrm{p}=$ 0.001). Larvae in day tows tended to be less abundant near to islands, particularly to the west (lee), and more abundant at oceanic stations (Fig. 4). Larvae tended to be least abundant in the southwest sector of the survey area, this being particularly evident in night tows (Fig. 4). Abundance of E. volitans larvae was not significantly correlated with either moon phase or flotsam abundance in either day or night tows (Spearman rank correlation: for day samples vs moon, $r_{s}=-0.167, p=0.466$; for night samples vs moon, $r_{s}=-0.233, p=0.330$; for day samples vs flotsam, $r_{\mathrm{s}}=0.303, \mathrm{p}=0.187$; for night samples vs flotsam, $r_{s}=0.087, p=0.706 ; n=20$ in all cases). Moreover, abundance was not correlated with salinity, temperature, $\mathrm{PO}_{4}-\mathrm{P}$ or $\mathrm{NO}_{3}-\mathrm{NO}_{2}-\mathrm{N}$ in either day or night tows (Spearman rank correlation; $\mathrm{p}>0.1$ in all cases).

\section{Parexocoetus brachypterus}

A total of 344 larvae of Parexocoetus brachypterus with a mean abundance of 2.45 fish $\mathrm{nmi}^{-1}$ tow and a mean size of $20.02 \mathrm{~mm}$ FL was collected by the 159 neuston tows over the survey area. As for all juvenile flyingfish and Exocoetus volitans, abundance of $P$. brachypterus larvae was significantly greater in day tows than night tows (Tables 4 \& 5; Mann-Whitney test: $Z=$ 2.065, $\mathrm{n}=159, \mathrm{p}=0.039$ ), and mean larval size was significantly greater at night (Fig. 5; Mann-Whitney test: $Z=$ $-11.934, \mathrm{n}=291, \mathrm{p}<0.001)$. Consequently, day and night samples have been considered separately in subsequent analyses.

Fig. 3. Exocoetus volitans. Length ( $\mathrm{mm}$ fork length, $\mathrm{FL}$ ) distributions of larvae in day and night neuston tows across the survey area 


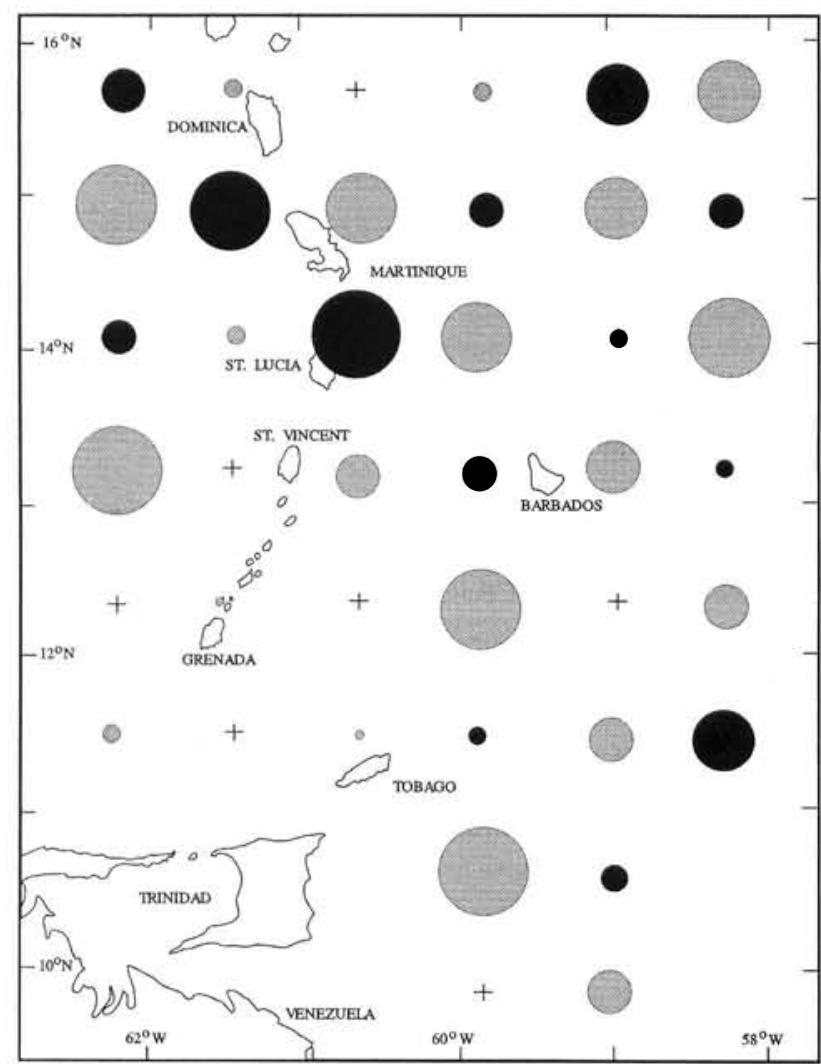

Fig. 4. Exocoetus volitans. Relative abundance in neuston tows sampled by (๑) day (small larvae) and by (-) night (large larvae) across the survey area. Area of circle is proportional to the mean abundance for each data set separately (range for day samples is 0.3 to 31.0 fish $\mathrm{nmi}^{-1}$ tow; range for night samples is 0 to 6.93 fish $\mathrm{nmi}^{-1}$ tow). (+) station without E. volitans island chain and Barbados and Tobago was again detectable (Fig. 6). Abundance of P. brachypterus larvae was higher with proximity to full moon in both day and night tows (Spearman rank correlation: for day samples, $\mathrm{r}_{\mathrm{s}}=0.442, \mathrm{p}=0.054$; for night samples, $\mathrm{r}_{\mathrm{s}}=$ $0.560, \mathrm{p}=0.009 ; \mathrm{n}=20$ in both cases); and was positively correlated with flotsam abundance in night tows (larger larvae) but not day tows (smaller tows) (Spearman rank correlation: for night samples, $\mathrm{r}_{\mathrm{s}}=$ $0.526, \mathrm{p}=0.022$; for day samples, $\mathrm{r}_{\mathrm{s}}=-0.038, \mathrm{p}=$ $0.868 ; \mathrm{n}=20$ in both cases). Abundance of $P$. brachypterus larvae was not correlated with salinity, temperature, $\mathrm{PO}_{4}-\mathrm{P}$ or $\mathrm{NO}_{3}-\mathrm{NO}_{2}-\mathrm{N}$ in either day or night tows (Spearman rank correlations; $\mathrm{p}>0.06$ in all cases).

\section{Cypselurus cyanopterus}

Only 63 larvae of Cypselurus cyanopterus with a mean abundance of 0.45 fish $\mathrm{nmi}^{-1}$ tow and a mean size of $11.92 \mathrm{~mm}$ FL were collected by the 159 neuston tows across the survey area. As for the previous species, abundance of $C$. cyanopterus larvae was significantly greater in day tows than night tows (Tables 4 \& 5; Mann-Whitney test: $Z=-2.766, \mathrm{n}=159, \mathrm{p}=0.006$ ), and mean larval size was significantly greater at night (Fig. 7; Mann-Whitney test: $Z=3.618, \mathrm{n}=51, \mathrm{p}<$ 0.001). There was a tendency for larvae of $C$. cyanopterus to be more abundant at northern stations than southern stations, and to be particularly rare in the southwest sector of the survey area (Fig. 8).
Abundance of Parexocoetus brachypterus larvae varied significantly between stations across the survey area (Table 5; Kruskal-Wallis test: for day samples, i.e. smaller larvae, $H=56.578$, $\mathrm{n}=80, \mathrm{p}<0.001$; for night samples, i.e. larger larvae, $H=44.211, \mathrm{n}=79, \mathrm{p}<$ 0.009). In contrast to Exocoetus volitans, there was a tendency most evident in day tows for larvae of $P$. brachypterus to be more abundant near to islands than at oceanic stations, and to be most abundant towards the southwest sector of the survey area (Fig. 6). Consistent with this, abundance of $P$. brachypterus larvae was negatively correlated with that of $E$. volitans larvae in day tows (Spearman rank correlation: $\mathrm{r}_{\mathrm{s}}=-0.394, \mathrm{n}=20, \mathrm{p}=$ 0.0005). A weak tendency for abundance to be low in a band running northeast between the Lesser Antilles

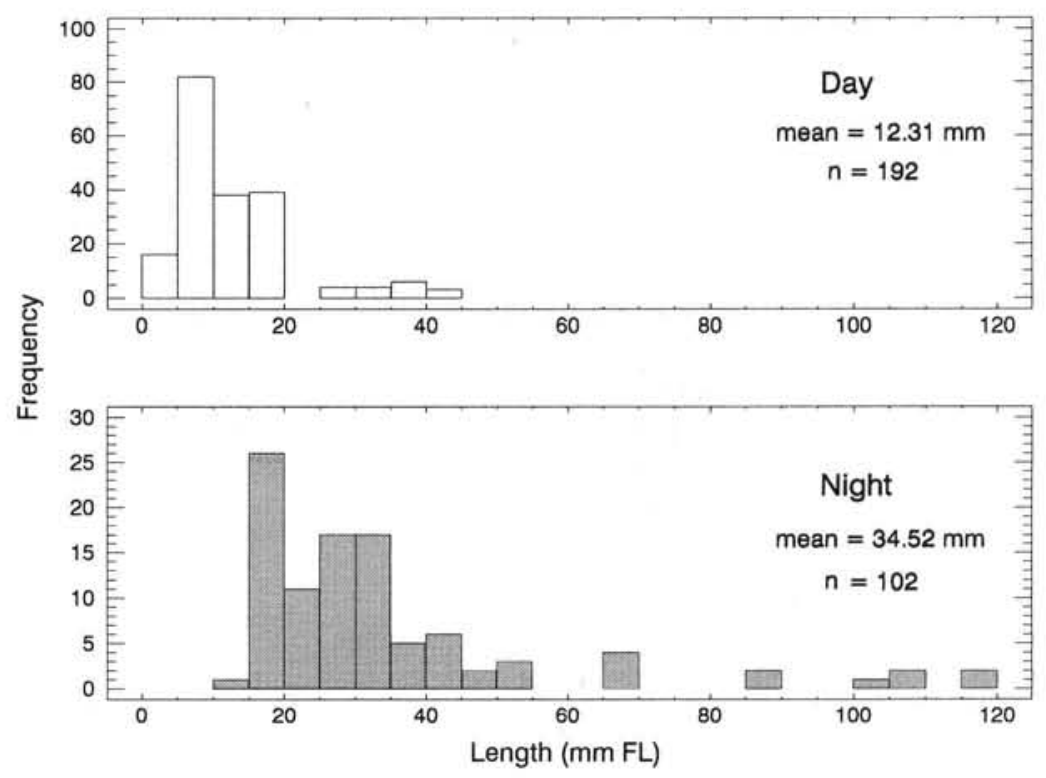

Fig. 5. Parexocoetus brachypterus. Length distributions of larvae in day and night neuston tows across the survey area 


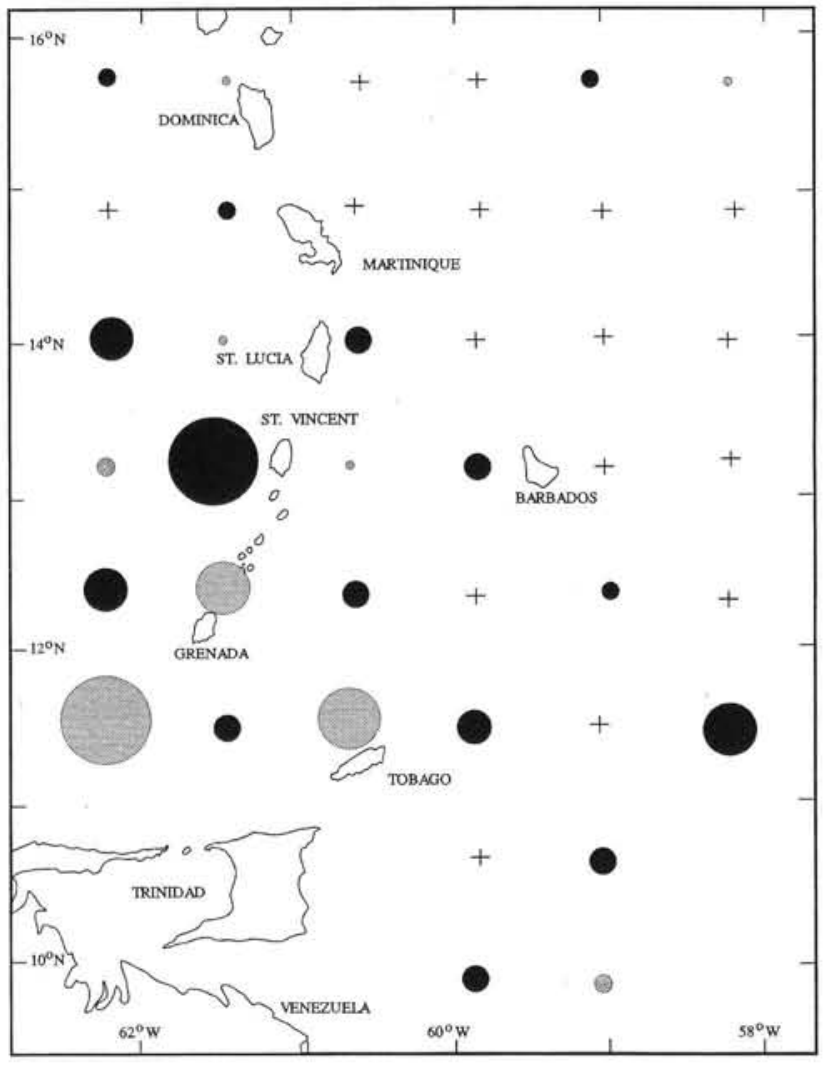

Fig. 6. Parexocoetus brachypterus. Relative abundance of larvae in neuston tows sampled by ( $\bigcirc$ ) day (small larvae) and by (-) night (large larvae) across the survey area. Area of circle is proportional to the mean abundance for each data set sep-

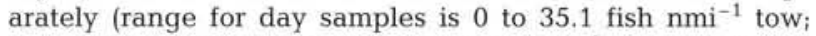
range for night samples is 0 to 12.5 fish $\mathrm{nmi}^{-1}$ tow). (+) station without $P$. brachypterus

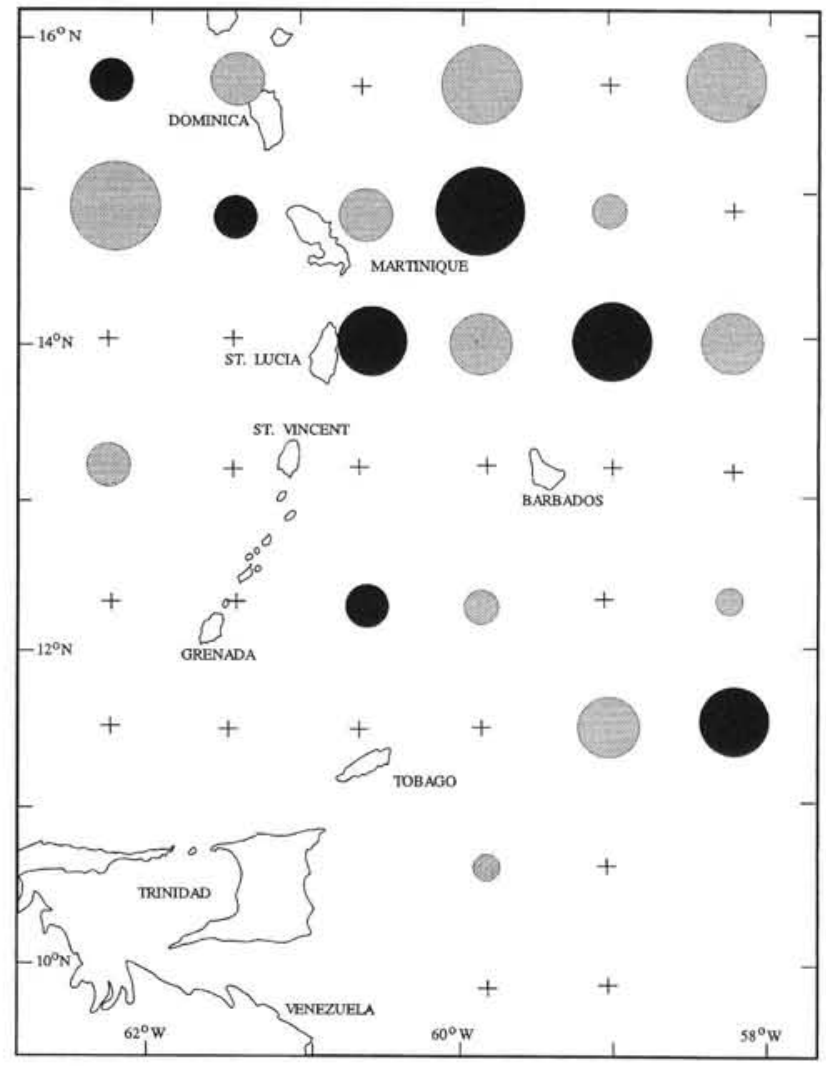

Fig. 8. Cypselurus cyanopterus. Relative abundance of larvae of Cypselurus cyanopterus in neuston tows sampled by (๑) day (small larvae) and (-) night (large larvae) across the survey area. Area of circle is proportional to the mean abundance (range for day samples is 0 to $2.4 \mathrm{fish} \mathrm{nmi}^{-1}$ tow; range for night samples is 0 to 1 fish $\mathrm{nmi}^{-1}$ tow). (+) station without C. cyanopterus

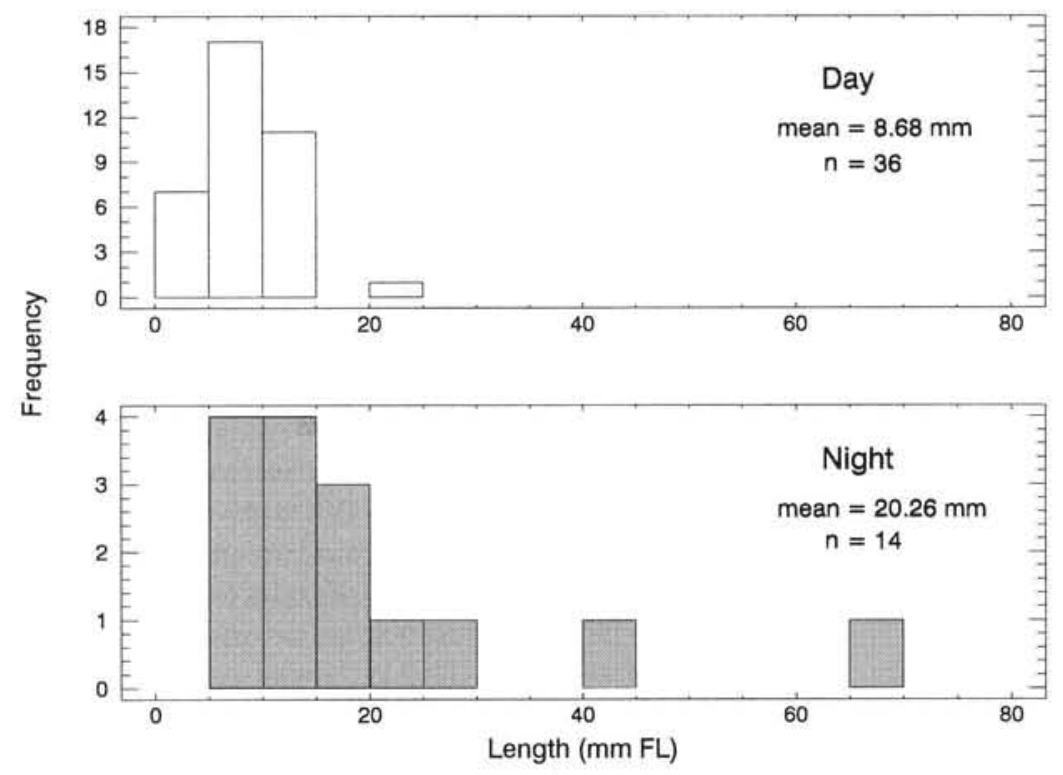

Fig. 7. Cypselurus cyanopterus. Length distributions of larvae in day and night neuston tows across the survey area

\section{Hirundichthys affinis}

Only 31 larvae of Hirundichthys affinis with a mean abundance of 0.22 fish $\mathrm{nmi}^{-1}$ and a mean size of 22.97 $\mathrm{mm}$ FL were collected by the 159 neuston tows across the survey area. Abundance did not differ significantly between day tows and night tows (Table 4; Mann-Whitney test: $Z=$ $-1.126, \mathrm{n}=159, \mathrm{p}=0.260$ ), but mean larval size was again significantly greater in night tows (mean for night: $36.4 \mathrm{~mm}$ FL, mean for day: $13.7 \mathrm{~mm}$ FL; Mann-Whitney test: $Z=2.739, \mathrm{n}=$ $27, p=0.006$ ). The small number of $H$. affinis larvae collected precludes description of their geographical distribution. 


\section{DISCUSSION}

Since flyingfish eggs, except those of Exocoetus and Prognichthys, are not buoyant and adults readily spawn on floating material (flotsam) (e.g. Brown 1942, Hall 1955, Lewis et al. 1962, Kovalevskaya 1982), it is commonly assumed that spawning on surface flotsam is the typical mode of reproduction in most flyingfish (Collette et al. 1984). Flotsam occurred in only $43 \%$ of the neuston tows conducted in this study, and its abundance by weight was less than $1 \mathrm{~g} \mathrm{nmi}^{-1}$ tow. Furthermore, flotsam items were only observed on $47 \%$ of the visual survey transects, and abundance by number of items was only 0.03 items $\mathrm{nmi}^{-1}$ of survey. These results are consistent with those of Lao (1989) who recorded flotsam in only $38 \%$ of neuston tows conducted year-round off Barbados (mean abundance $<0.01 \mathrm{~g} \mathrm{nmi}^{-1}$ tow), and recorded only a single sighting of flotsam along a $6 \mathrm{nmi}$ onshore-offshore transect off Barbados visually surveyed once a week for a full year (mean abundance 0.003 items $\mathrm{nmi}^{-1}$ survey). The scarcity of surface flotsam is surprising since water originating in the river basins of South America is known to be transported through the survey area by the Guiana Current, particularly between March and September (Lewis et al. 1962, Froelich et al. 1978, Borstad 1982a, b, Muller-Karger et al. 1989).

Consistent with the scarcity of surface flotsam, nonbuoyant flyingfish eggs were collected in negligible quantities across the eastern Caribbean. The absence of non-buoyant flyingfish eggs cannot have resulted from an absence of spawning adults, since adults of Hirundichthys affinis and Parexocoetus brachypterus are abundant in the eastern Caribbean (Oxenford et al. 1995), and the survey was conducted during the known spawning periods of both $H$. affinis and $P$. brachypterus (see 'Methods, Study area'). Moreover, coconut fronds (which act as fish attracting devices (FADs) as well as spawning substrata) set at night stations specifically to test whether flyingfish were in spawning condition during the time of the survey confirmed this by the frequent presence of $H$. affinis eggs on the fronds; and data on $H$. affinis landed in Barbados indicated that $43 \%$ of males and $49 \%$ of females were running ripe during the months of the survey (Khokiattiwong 1988). Lao (1989) also reported a scarcity of $H$. affinis eggs off Barbados, recording eggs in only 5 of 431 tows conducted over a $1 \mathrm{yr}$ period, and in only 2 of 31 tows conducted during the same period as this study (April to May 1988).

The scarcity of surface flotsam and eggs indicates that spawning on floating material which remains at the surface is not the typical mode of reproduction in either Hirundichthys affinis or Parexocoetus brachypterus. Plausible alternatives are that flyingfish spawn so profusely on available surface flotsam that it causes both eggs and flotsam to sink, or that flyingfish typically spawn on submerged or benthic substrata. Qualitative observations on $H$. affinis support both the sinking of flotsam and the spawning on submerged substrata. FADs set by commercial fishermen can become so laden with eggs that they sink when freed from the boat, and a preliminary study of $H$. affinis spawning off Tobago has demonstrated that $H$. affinis will spawn on submerged substrata at least as far as $20 \mathrm{~m}$ below the surface (Oxenford et al. 1993). Furthermore, laboratory-reared larvae of $H$. affinis were observed to orient vertically (head up, tail down) and swim continously for the first $3 \mathrm{~d}$ following hatching. After $3 \mathrm{~d}$ they oriented horizontally and clustered near the surface by day, but sank deeper by night (pers. obs.). The willingness of $H$. affinis to spawn at depth raises the possibility that it may also opportunistically spawn on benthic substrata. However, since $H$. affinis is not typically found close to shore, and since island shelves in the eastern Caribbean are narrow, it is unlikely that benthic spawning is common in this species. Interestingly, Kovalevskaya (1982) reported that Parexocoetus spp. typically spawn on coastal algae, intimating benthic spawning in this genus.

The low abundance of buoyant Exocoetus volitans eggs is not surprising given the virtual absence of adults in the survey area (Oxenford et al. 1995), and suggests oceanic spawning primarily outside of the survey area. This is consistent with previous studies indicating that $E$. volitans is an oceanic species (Gibbs 1978, Kovalevskaya 1982, Grudtsev et al. 1987). The low overall abundance of $E$. obtusirostris eggs, but relatively high abundance at a single coastal station, may reflect the apparent preference of this essentially oceanic species to spawn in areas of coastal upwelling (Grudtsev et al. 1987).

Larval fish were abundant across the survey area, a total of 13289 from at least 28 families being collected. Catch rates for all fish larvae and for flyingfish larvae recorded in this study are about twice those reported by Lao (1989) using the same gear over the same months (April to May 1988) off the northwest of Barbados. However, taxonomic composition of catch was similar in the 2 studies. Catch rates reported by Richards (1984) for the wider Caribbean for all fish larvae and for flyingfish larvae are between those reported by Lao (1989) and the present study. The lower catch rates of Lao (1989) may indicate a lower abundance of neustonic fish off Barbados than typical of the eastern Caribbean, and/or lower sampling efficiency of the gear. The latter is plausible, given the lower maximum towing speed of the small research vessel used in Lao's study ( 3 knots versus present study tow rate of 2.8 to 4.0 knots). Catch rates for all 
fish larvae in day tows were about twice that in night tows in this study and that of Lao (1989), and mean size of larvae was significantly greater in night tows than in day tows in both studies. Previous neuston tow studies are consistent with the difference in catch rate (e.g. Parin et al. 1972, but see Fahay 1975 for opposite result). Differences in catch rates and mean size may be partly the consequence of taxon-specific differences in diurnal vertical migration, since taxonomic composition differs between day and night samples (Lao 1989, this study). However, within flyingfish larvae, and separately for Exocoetus volitans, Parexocoetus brachypterus, Cypselurus cyanopterus and Hirundichthys affinis, larvae were more abundant and smaller in day tows than in night tows (Lao 1989, this study). Hempel \& Weikert (1972) suggested that flyingfish larvae concentrate at the surface by day and move deeper by night, and this is supported by our own observations of laboratory-reared flyingfish larvae. The movement to deeper water may be partly passive and size-specific. Parin (1967) reported decreased locomotor activity of smaller neustonic fish at night, suggesting that much of the neuston, but particularly smaller individuals, may sink below the sampling depth of neuston gear by night. This would explain both the reduced abundance and larger mean size characteristic of night tows. The size difference may also result from size-specific variation in gear avoidance behaviour by day and night. All larvae may be further from the surface by night, resulting in the lower night-time abundance, but the size structure of the sample may be representative of the population, since gear avoidance may be difficult for larvae of all sizes. However, larvae may visually detect the gear by day, and larger larvae may more effectively avoid it, thereby producing a smaller mean larval size by day than by night.

Abundance of Exocoetus volitans larvae was not significantly correlated with either flotsam abundance, moon phase or surface water characteristics. However, abundance of Parexocoetus brachypterus larvae was higher around full moon than new moon, and positively correlated with flotsam abundance in night tows (larger larvae) but not day tows (smaller larvae). The higher abundance around full moon may indicate greater locomotor activity on bright nights than dark nights, with fewer larvae sinking below the depth range of the gear on bright nights. The positive correlation between larval abundance and flotsam abundance could result from passive retention by currents of flotsam and larvae in similar locations, or from larvae actively associating with areas of high flotsam abundance. The latter seems more likely, since the correlation between larval and flotsam abundance was observed for larger but not smaller larvae.
The patchy local distribution characteristic of larvae and observed in this study may constrain attempts to reliably detect geographical variation in relative abundance. Specifically, high density patches can simply be missed, and even when encountered, may be undersampled through a gear saturation effect (see Simmonds et al. 1992). Despite constraints of local patchiness, abundance varied significantly across the survey area in the present study, for all flyingfish larvae combined, and separately for Exocoetus volitans, Parexocoetus brachypterus and Cypselurus cyanopterus, and geographical patterns in relative abundance were evident in many cases. For E. volitans, smaller larvae tended to be less abundant near islands, particularly to the west (lee), and more abundant at oceanic stations. In general the larvae were least abundant in the southwest sector of the survey area, i.e. near the South American mainland. The greater abundance of E. volitans larvae at oceanic stations, and the virtual absence of adults and eggs (Oxenford et al. 1995, this paper) indicate drift of early life stages from a spawning area primarily located outside of the survey area.

In contrast to Exocoetus volitans, smaller larvae of Parexocoetus brachypterus were more abundant close to islands. This is consistent with previous studies indicating that $P$. brachypterus occurs closer to land than E. volitans (e.g. Rao \& Basheeruddin 1973, Gibbs 1978). Moreover, in contrast to $E$. volitans, larvae of $P$. brachypterus were most abundant in the southwest sector of the survey area, near the South American mainland. Interestingly, there was a significant negative correlation between the abundance of small larvae of $P$. brachypterus and E. volitans, reflecting the more coastal distribution of the former and the more oceanic distribution of the latter.

Larvae of Cypselurus cyanopterus were more abundant at northern than at southern stations, and were particularly rare in the southwest sector of the survey area near the South American mainland. The results of the visual survey also indicate that adults of $C$. cyanopterus were essentially absent in the southwest of the survey area, and most abundant in the northeast (Oxenford et al. 1995).

Given the low numbers of larval Hirundichthys affinis collected, it was not possible to analyse or comment confidently on variation in abundance across the survey area. Adults of $H$. affinis are common in the eastern Caribbean, supporting important commercial fisheries in the region, and $H$. affinis was in spawning condition at the time of the survey. The scarcity of $H$. affinis larvae is therefore surprising. It may suggest that $H$. affinis larvae occur deeper than those of other flyingfish species, and emphasises the need to investigate the possibility that $H$. affinis may typically spawn on submerged substrata, or on surface substrata until 
they submerge. Large-scale spawning on surface substrata until they submerge could partly explain the observed scarcity of surface flotsam in an area known to be influenced by water from South American rivers, and presumed to be rich in flotsam at source.

Acknowledgements. This study was funded by IDRC (International Development Research Centre, Ottawa, Canada) as a component of the Eastern Caribbean Flyingfish Project. The many organisations and individuals who made contributions have been fully acknowledged in Paper I of this 3 part series.

\section{LITERATURE CITED}

Balon, E. K. (1985). The theory of saltatory ontogeny and life history models revisited. In: Balon, E. K. (ed.) Early life histories of fishes. Junk Publishers, Dordrecht, p. 13-28

Borstad, G. (1982a). The influence of the meandering Guiana Current and Amazon discharge on surface salinity near Barbados. J. mar. Res. 40: 421-434

Borstad, G. (1982b). The influence of the meandering Guiana Current on the surface conditions near Barbados: temporal variations of Trichodesmium (Cyanophyta) and other plankton. J. mar. Res. 40: 435-452

Breder, C. M. (1938). A contribution to the life histories of Atlantic Ocean flyingfish. Bull. Bingham Oceanogr. Coll. 6: $1-126$

Brown, H. H. (1942). The sea fisheries of Barbados. Development and Welfare in the West Indies, Bull. 1: 1-42

Bruun, A. Fr. (1935). Flying-fishes (Exocoetidae) of the Atlantic: sytematic and biological studies. Dana Rep. 6: $1-106$

Collette, B., McGowan, G., Parin, N., Mito, S. (1984). Beloniformes: development and relationships. In: Moser, H. G., Richards, W. J., Cohen, D. M., Fahay, M. P., Kendall, A. W. Jr, Richardson, S. L. (eds.) Ontogeny and systematics of fishes. American Society of Ichthyology and Herpetology, New York, Spec. Publ. 1., p. 335-354

Evans, J. W. (1961). Normal stages of the early development of the flyingfish, Hirundichthys affinis (Günther). Bull. mar. Sci. 11: 483-502

Fahay, M. P. (1975). An annotated list of larvae and juvenile fishes captured with surface towed meter net in the South Atlantic Bight during four 'Dolphin' cruises between May 1967 and February 1968. NOAA Tech. Rep. NMFS SSRF 685

Froelich, P. N. Jr, Atwood, D. K., Giese, G. S. (1978). Influence of Amazon River discharge on surface salinity and dissolved silicate concentration in the Caribbean Sea. Deep Sea Res. 25: 735-744

Gibbs, R. H. Jr (1978). Exocoetidae, flyingfishes. In: Fischer, W. (ed.) FAO species identification sheets for fishery purposes. Western Central Atlantic (fishing area 31). Vol. 2, pag. var. FAO, Rome

Grudtsev, M. E., Salekhova, L. P., Lushchina, V. G. (1987). Distribution, ecology and intraspecific variability of flyingfishes of the genus Exocoetus of the Atlantic Ocean. J. Ichthyol. 27: 39-50

Hall, D. N. F. (1955). Recent developments in the Barbadian flyingfish fishery and contributions to the biology of the flyingfish, Hirundichthys affinis (Günther 1866). Eng. Colonial Office Fishery Publ. 7, London

Hempel, G., Weikert, H. (1972). The neuston of the subtropical and boreal Northeastern Atlantic Ocean. A. Rev. mar. Biol. 13: 70-88
Imai, S. (1959). Studies on the life histories of the flyingfishes found in the adjacent waters of Japan. I. Mem. Fac. Fish. Kagoshima Univ. 7: 1-85 (English summary)

Imai, S. (1960). Studies on the life histories of the flyingfishes found in the adjacent waters of Japan. II. Mem. Fac. Fish. Kagoshima Univ. 8: 8-45 (English summary)

Kendall, A. W. Jr, Ahlstrom, E. H., Moser, H. G. (1984). Early life history stages of fishes and their characters. In: Moser, H. G., Richards, W. J., Cohen, D. M., Fahay, M. P., Kendall, A. W. Jr, Richardson, S. L. (eds.) Ontogeny and systematics of fishes. American Society of Ichthyology and Herpetology, New York, Spec. Publ. 1., p. 11-22

Khokiattiwong, S. (1988). Seasonality and abundance of Hirundichthys affinis and Parexocoetus brachypterus. M.Sc. thesis, McGill University, Montreal

Kovalevskaya, N. V. (1964). Study of development of the 'twowinged' flying fishes of the genus Exocoetus (Exocoetidae, Pisces). Tr. Inst. Okeanol. Akad. Nauk. SSSR 73: 204-223 (English summary)

Kovalevskaya, N. V. (1982). Superfluous reproduction and development of flying fishes of the family Exocoetidae. J. Ichthyol. 22: 48-54

Lao, M. R. (1989). Distribution and abundance of flotsam, larval fish and juvenile fish off Barbados with particular reference to the Exocoetidae. M.Sc. thesis, McGill University, Montreal

Lewis, J. B. (1961). The growth, breeding cycle and food of the flyingfish Parexocoetus brachypterus hillianus (Gosse). Bull. mar. Sci. 11: 258-266

Lewis, J. B., Brundritt, J. K., Fish, A. G. (1962). The biology of the flyingfish Hirundichthys affinis (Günther). Bull. mar. Sci. Gulf Carib. 12: 73-94

Mahon, R., Oxenford, H., Hunte, W. (eds.) (1986). Development strategies for flyingfish fisheries of the eastern Caribbean, Workshop proceedings, IDRC-MR128e. International Development Centre, Ottawa

Muller-Karger, F. E., McClain, C. R, Fisher, T. R., Esaias, W. E., Varela, R. (1989). Pigment distribution in the Caribbean Sea: observations from space. Prog. Oceanogr. 23: 23-69

Munro, I. S. R. (1954). Eggs and larvae of the four-winged flying fish, Hirundichthys speculiger (Valenciennes). Aust. J. mar. Freshwat. Res. 5: 64-69

Oxenford, H. A., Mahon, R., Hunte, W. (eds.) (1993). The Eastern Caribbean Flyingfish Project. Organisation of Eastern Caribbean States (OECS) Fishery Report 9, St. Vincent

Oxenford, H. A., Mahon, R., Hunte, W. (1995). Distribution and relative abundance of flyingfish (Exocoetidae) in the eastern Caribbean. I. Adults. Mar. Ecol. Prog. Ser. 117: $11-23$

Parin, N. V. (1967). Diurnal variations in the larval occurrence of some oceanic fishes near the ocean surface. Oceanology 7: $115-121$

Parin, N. V., Gorbunova, N. N., Chubasov, V. M. (1972). Quantitative distribution of the near-surface ichthyoplankton in the eastern Pacific Ocean (based on trawls with a towed neuston otter trawl). Oceanology 12: 894-899

Richards, W. J. (1984). Kinds and abundance of fish larvae in the Caribbean Sea and adjacent waters. NOAA Tech. Rep. NMFS SSRF-776

Rao, K. S., Basheeruddin, S. (1973). Unusual catches of the flyingfish, Parexocoetus brachypterus brachypterus (Richardson) in inshore waters at Madras. Indian J. Fish. 20: 629-634

Sameoto, D. D., Jaroszynski, L. O. (1969). Otter surface sampler: a new neuston net. J. Fish. Res. Bd Can. 26: 2240-2244 
Simmonds, E. J., Williams, N. J., Gerlotto, F., Aglen, A. (1992). Acoustic survey design and analysis procedure: a comprehensive review of current practice. ICES Cooperative Research Report 187, Copenhagen

Smith, P. E., Richardson, S. (1977). Standard techniques for pelagic fish eggs and larval surveys. FAO Fish. Tech. Pap. 175, Rome

This article was submitted to the editor
Storey, K. W. (1983). Aspects of the biology and fishery of the flyingfish, Hirundichthys affinis, at Barbados. M.Phil. thesis, University of the West Indies, Barbados

Vijayaraghavan, P. (1973). Studies on fish eggs and larvae from Indian waters. I. Development of egg and larvae of Hirundichthys coromandelensis (Hornell). Indian J. Fish. 20: $108-137$

Manuscript first received: March 8, 1994

Revised version accepted: October 4, 1994 